\title{
Big Business and White Insecurities at the End of Empire in Southern Africa, c.1961-
} 1977

Andrew Cohen

School of History, University of Kent, Canterbury, United Kingdom and the International Studies Group, University of the Free State, Bloemfontein, South Africa

Rory Pilossof

Department of Economics, University of the Free State, Bloemfontein, South Africa

\begin{abstract}
This paper examines popular and widespread mistrust of large-scale capitalism, and its potential for disloyalty to the post-1965 Rhodesian state, by the white middle class and smallscale capitalists in Rhodesia. It focuses on the relationship between Roland 'Tiny' Rowland, managing-director of the multinational Lonrho company, and Wilfred Brooks, the editor of the largest business/trade journal in Rhodesia, Rhodesian Property \& Finance. This case is augmented with observations on the role and actions of other multinationals such as the Anglo American Corporation and the newspaper conglomerate of the Argus Press, which illustrate how white, urban, small-scale capital responded to the political changes underway. A close reading of Property \& Finance in the early 1960s suggests there was a general fear of large-scale business enterprise without firm Rhodesian roots. As the 1960s progressed, this fear morphed into concerns of big businesses' relationship with African nationalists and the pan-African movement. Many saw these companies as too friendly with new African political entities. In particular, Rowland's willingness to work with independent Africa, and particularly the Organisation of African Unity, was of crucial importance in shaping the way in which Property \& Finance engaged with Lonrho's business activities. These findings illustrate key divisions within the white community during a time of radical change. Furthermore, they cast light on the contested, and often contradictory, role played by these multinational companies during the era of decolonisation and political change in southern Africa.
\end{abstract}

\section{Key words}

Rhodesia, capitalism, big business, Lonrho, Property \& Finance, Wilfred Brooks, Anglo American

\section{Introduction}

In January 1962, the Southern Rhodesian business periodical Rhodesian Property \& Finance published an article on its front page titled: 'Mystery of S.R. gold mine's "vanished" reserves'. ${ }^{1}$ The piece examined the 1960-61 annual reports of Kanyemba Gold Mines Ltd., which contained 'certain conflicting figures'. The article suggested that many small shareholders had accepted the claim made in the 1960 annual report that the mine possessed 'the official "expectation" of twenty years of "proved" ore reserves', only to find out a year 
later that its adjusted life was a mere eighteen months. This revelation had seen the company's shares slump from $£ 1$ to 2 s. $6 \mathrm{~d}$. each. ${ }^{3}$ After reading the article, Roland 'Tiny' Rowland, Lonrho's joint managing-director in Salisbury, was incensed and attempted to speak with the magazine's editor, Wilfred Brooks, on the telephone. Brooks refused to take Rowland's first two calls but relented at Rowland's third attempt. Brooks would later recall how Rowland's voice was 'quivering with angry affront' as they discussed the article. Brooks, in an attempt to defuse the conversation, then interjected: 'you seem to think, Mr. Rowland, that our analysis was a personal attack; but as you know, I have never had the pleasure of meeting you'. According to Brooks, Rowland's temperament changed instantly as he responded 'Oh, yes Mr. Brooks ... that is exactly why I am inviting you to discuss the matter personally with me'.

The following day Brooks decided to accept the invitation and crossed the street to Rowland's office. Discussions over the article lasted for two hours. At one point during the talks, Rowland allegedly exclaimed 'Mr. Brookes, I love Rhodesia; and I am working to build up Rhodesia. Yet you and a journal like Property \& Finance bother about a silly little thing like Kanyemba! ${ }^{5}$ Eventually Brooks offered Rowland 1,000 words to respond to the allegations made. Brooks' offer was, however, on the condition that Rowland should personally sign the reply. Rowland reacted angrily, instructing Brooks that he was 'not interested in submitting a signed statement. But what I do expect you to do Mr. Brooks, in the interests of Rhodesia, is to say in your next issue that, after full discussions with $\mathrm{Mr}$. Rowland, your comments on Kenyemba were totally unjustified'. ${ }^{6}$ Brooks was appalled at Rowland's suggestion and colourfully noted how 'the picture of the gypsy fiddler (the only picture in the office) seemed to grin even more malevolently; and the Siamese cat on the cover of the only book on Mr. Rowland's desk seemed to lick its lips with anticipation'?

This article traces the relationship between big business and white insecurities, as presented in Property \& Finance, during the 1960 and 1970s. In doing so it sheds light on the relationship between Brooks and Rowland whose enmity was more than just a private matter. From 1960 until the magazine's closure in 1976, Brooks took every opportunity available to castigate Lonrho and Rowland in print. These attacks reflected Brooks' beliefs about the role of big business in southern Africa during a highly-contested period in the region's history. The granting of independence to a vast number of colonies across Africa that started in the late 1950s spread to southern Africa in the 1960s, with Malawi, Zambia, Tanzania and Botswana awarded self-rule during that decade. The white minority government in Rhodesia, however, contested these changes and resisted majority rule, as did South Africa and the 
Portuguese colonies of Mozambique and Angola. Rhodesian intransigence led to the colony's Unilateral Declaration of Independence (UDI) in 1965. Brooks embraced these developments and Property \& Finance became highly politicised, extremely right wing and very populist. A central tenant of this populism was that big business, typified by individuals like Rowland and Lonrho, undermined the aspirations of ordinary white Rhodesians by making hasty and ill-considered deals with black nationalist leaders and movements, and putting profit before white interests and security.

The potential for using Property \& Finance as a lens through which to examine the shifting attitudes of white Rhodesian society was first hinted at in Godwin and Hancock's pioneering work on Rhodesian society during the 1970s. ${ }^{8}$ References to Brooks and his publication's approach to UDI are scattered through their work and offered the reader a tantalising glimpse of the possibilities that a systematic study of the journal offered in shedding new light on the complexities of Rhodesian settler society. More recent scholarship of Rhodesian settler society on this period has tended to focus on demographic change, the role of white women and politics or accounting for the high political manoeuvres of the rebel regime and the British state. ${ }^{9}$ This article charts a different course, using Property \& Finance to explore key divisions within the white community during a time of radical change.

\section{Wilfred Brooks and the Establishment of Property \& Finance}

Wilfred Brooks moved to Rhodesia in 1948 from South Africa, having been born in Essex, England in 1915. He already had an established career working in newspapers and journals in Cape Town, Johannesburg and Pretoria before the Second World War. After the war and until released from service, he was a member of the special staff in Germany training local journalists. ${ }^{10}$ Once demobilised, he worked in the London office of Argus South Africa newspapers. He returned to Africa to pursue his business interests and moved to Rhodesia shortly after, settling in Bulawayo. ${ }^{11}$ There, he became very active in local politics. By 1954 he was chairman of the Hillside (a suburb in Bulawayo) branch of the United Rhodesia Party; chairman of the Hillside Ratepayers Association, secretary of the Umguza (a district in the province of Matabeleland North and close to Bulawayo) branch of the Federal Party; chairman of the Publicity Committee 'Boost Bulawayo' campaign and a member of the Bulawayo Civic and Ratepayers Association. ${ }^{12}$ In 1954 he stood as a United Federal Party (UFP) candidate for the territorial parliament, but lost. ${ }^{13}$

The rise in economic activity in the Federation opened up opportunities for dedicated publications for the business sector. To this end, Gerrard Aberman, who had long been 
involved in numerous periodicals, established the journal Rhodesian Property \& Finance in 1956. ${ }^{14}$ Initially, Property \& Finance was a monthly periodical focused on property sales and management issues within Salisbury, the capital of Southern Rhodesia. The readership of the magazine grew fast as it filled a niche that many in the business community found useful. By 1958, Property \& Finance could state that it had the largest paid circulation of any monthly business or trade journal in the Federation, with over $80 \%$ prepaid annual subscribers and was read by 'most industrialists, managers, officials and even the Prime Minister of the Federation'. ${ }^{15}$ The success of the journal resulted in its expansion and rapid growth and Brooks was appointed as managing-editor in $1959 .{ }^{16}$ As Property \& Finance grew, it began to devote more coverage to general business, rural issues, and 'also national affairs, especially as political developments impinged increasingly on economic and business prospects'. ${ }^{17}$ By 1962 it had the highest paid circulation of any business periodical in central Africa, as assessed by the Audit Bureau of Circulations of South Africa. By 1971, it claimed a monthly distribution to 41,000 readers, which increased to 52,000 in 1975 and 71,000 in $1977 .^{18}$

Brooks wrote all the political and political-economic commentaries for the magazine until its closure in 1977. Typically, each issue of the magazine contained a long and investigative piece discussing developments and highlights of the previous month, along with general business and property coverage. These pieces, composed by Brooks, offer a key to understanding his thinking and political sympathies. In 1959 Brooks was very clearly in the 'liberal' camp, holding the belief that Africans deserved political and economic freedoms, in order to maintain a level of racial partnership. By 1962, however, this outlook had changed radically. With the collapse of the Central African Federation in December 1963 and the spread of independence across much of Africa, Brooks felt that white interests in Africa were under attack. Brooks became much more conservative, right wing and overtly racist. ${ }^{19}$ This shift coincided with the rise of the Rhodesian Front (RF). Brooks actively encouraged his readers to back the party in their bid to stop majority rule and ensure continued white control of Southern Rhodesia. ${ }^{20}$ Wilfred Brooks also supported the ascendency of Ian Smith to leader of the RF and the push for UDI in 1965. By the end of the 1960s, however, Brooks felt that Smith was a fraud who had betrayed white interests in Rhodesia. He accused him of holding secret talks with British and nationalist leaders in which he undermined the future prospects of white settlers. Brooks resigned from the RF and became an active supporter of a number of radical opposition movements, such as the extremely right-wing Southern African Solidarity Conference (SASCON). ${ }^{21}$ 


\section{The Populist Shift in Property \& Finance}

Property \& Finance found an audience through reflecting popular white concerns. As Patrick Bond observed, political sensibilities of various sectors of the white community in Rhodesia were often dictated by their economic position. Industrial and financial capitalists saw the need for the expansion of a black middle class to provide a growing domestic market. Other whites, however, particularly urban, small-scale capitalists and waged workers, were concerned about growing African urban populations. The main concerns centred on possible rising labour costs, competition in the work place, sharing amenities and being unable to keep black populations in check. ${ }^{22}$ It is this second camp that Brooks and Property \& Finance appealed to in the 1960s. Consequently, the liberal messages that Brooks promoted in the 1950s disappeared and were replaced by a staunch defence of white rights and interests, intermixed with derogatory statements on African capabilities, potential and worth.

Part of this shift resulted in a reframing of foreign capital and big business in Property \& Finance. Brooks sought to establish a greater connection with, what he called, the 'ordinary man in the street', meaning white urban Rhodesians not associated with big capital. ${ }^{23}$ Brooks attempted, through Property \& Finance, to connect with local and regional white audiences trying to make sense of the changes occurring in the region. The magazine tapped into white fears of what could happen with the process of decolonisation that was underway. Brooks supported the RF, Ian Smith and UDI in 1965, because he felt that this was the best course of action to secure the futures and interests of white Rhodesians. As Arrighi has noted, UDI, in its initial conception, 'was directed as much against large-scale capitalism as against the Africans. The populist undertones of the UDI campaign were very noticeable'. ${ }^{24}$ Brooks encapsulated those populist undertones and used his magazine to promote and disseminate this discourse. The shift of Brooks and his utterances in Property \& Finance support such Arrighi's claim and also illustrate how powerful this message was.

As part of his populist stance, Brooks raised questions over the role of big business in the politics of the day. These concerns saw Property \& Finance attack a number of large corporations, including Lonrho. ${ }^{25}$ In July 1960, Brooks had written that it was no secret that 'powerful business interests, shocked and angry at circumstances leading to the Southern Rhodesia riots last month [July 1960], have been exerting pressure on the Government to reassess the political situation'. ${ }^{26}$ By 1963, this pressure had become too much for Brooks. In response to the intrusion of big capital into the political jostling at the time, Brooks became more defensive of small capitalists and white workers. In January Brooks assured his readers that Property \& Finance was there to that look out for the little man, Rhodesians who made 
Rhodesia and had to live here and deal with the 'African'. ${ }^{27}$ This populist stance, at odds with Brooks' earlier writings on big business, became a mainstay of the magazine. Brooks warned businesses that had been involved with African independence leaders: 'Powerful companies, who have been flirting with the nationalist parties in the north, may well live to regret their expediency'. ${ }^{28}$ This jibe was directed at Rowland and Lonrho in particular. By late 1963 Brooks felt that:

Business has swung in support of the ordinary [white] man-in-the-street, whose attitudes are quite clear: he has tried to meet Pan-Africanism half-way; he has accepted what (in Southern Africa) is a radical constitution; he has gone about his daily business, in complete confidence that he as a moral as well as a demonstrable case after 40 years or reasonable and pretty fair self-government; and he has not the slightest intention of appeasing more, until he sees what happens in the African territories to the north of him. ${ }^{29}$

Property \& Finance had clearly changed and the tone and focus of the magazine had shifted radically from its earlier stance. As the threats of majority rule and African takeover grew, Brooks began to see the big corporations such as Lonrho and the Anglo American Corporation (Anglo) in cahoots with the Organisation of Africa Unity (OAU), which he felt was anti-white and threating to a continued white presence on the continent. These apparent links, and the threat they posed, became the key focus of Brooks' offensive against big capital and big business.

Brooks' political commentary caused friction with the periodical's owner, Gerrard Aberman. So much so that in 1967, Brooks tendered his resignation over an attack of the magazine by the then Minister of Information, Mr. Howman, and the lack of support he felt he had received from his proprietor. Brooks then sought to establish a rival fortnightly publication, with backing from an investment consultant, Mr. N.E. Oldenburg. A consortium of local businessmen, however, backed by 400 Rhodesian investors, established the Rhodesian Newspapers Trust, which purchased Property \& Finance in November and promptly reinstated Brooks as the editor. ${ }^{30}$ The magazine now proudly proclaimed on its cover that it was 'owned, financed and controlled in Rhodesia. Supported by "Friends of Rhodesia" abroad'. 31 A director of Property \& Finance later noted that when the Trust purchased the paper, they informed Brooks that he would have editorial freedom with regard to economic and financial content, 'but he was to restricted to non-party-political comment, since we did not want to become associated with either side of the political spectrum' ${ }^{32}$ Brooks, however, ignored these warnings and continued to castigate many in the RF, including Smith. Some board members were embarrassed by these attacks and Brooks was 
asked to leave, however a cabal of more right-wing colleagues staged an intervention to have Brooks reinstated. The original Trust then sold Property \& Finance to a newly incorporated company, which was 'entirely Rhodesian'. Brooks now had free reign to tout his political message, which he dressed up as 'fully Rhodesian owned', and putting 'Rhodesia First', to tie into his popular positioning. ${ }^{33}$ To Brooks these qualities represented everything Lonrho's managing-director lacked.

\section{Lonrho and 'Tiny' Rowland}

'Tiny' Rowland moved to Southern Rhodesia in 1948. After settling in Gatooma, Rowland set about developing his business interests in a holding company called Shepton Estates. 'By around 1958', as Richard Hall, the editor of the Lonrho-owed Times of Zambia in the 1960s later recalled,

there was some awareness in Salisbury that a formidable - and rather disturbing personality had arrived on the financial scene. Rowland was enigmatic; he was not a clubbable man. There were even rumours put about that he was a homosexual. His dealings were being remarked upon in local business journals; sometimes the inferences were harsh. He paid no heed: his astuteness had earned him access to funds in Johannesburg when credit was hard to come by in Salisbury. ${ }^{34}$

Rowland's first visit to Kanyemba, referred to in the introduction, during 1958 was later recalled by Ken Adams, the mine's manager, who saw 'a Rolls Royce Silver Cloud manoeuvre over the dirt track road towards the mine ... From the car, a tall man in a Citystyle tweed suit, waistcoat and monogrammed silk shirt emerged' ${ }^{35}$ It was clear to Adams that Rowland had little knowledge of gold mining. The Rhodesia Selection Trust (RST) group had initially held an option on the mine, however, its chairman Sir Ronald Prain decided against exercising it in 1958 after receiving a negative survey of the mine's prospects from the group's consulting geologist. Soon afterwards the mine piqued the interest of Rowland who swiftly purchased Kanyemba and also struck a deal to secure the adjacent Hepworth mine.

Rowland's intention was to float the two mines on the Johannesburg stock exchange, yet to do so successfully he needed a positive report from an independent consulting engineer. Rowland settled on a South African mining engineer named Roelof Radmeyer who had developed an expertise in surveying coalmines but had little experience of gold workings. Radmeyer's brief had been identical to that of RST's consulting engineer but his conclusions could not have been more different. He failed to mention the previous report at all and Radmeyer's own report was liberally sprinkled with optimistic phrases. With the report 
secured, Rowland issued 1.5 million shares with a value of $£ 450,000$. This was virtually double the amount that Rowland had paid for the two mines. He retained 60 per cent of the shares and offered the public 600,000 shares at 37.5 pence. Rowland would later transfer his shareholding to Lonrho as part of his appointment package in 1962. ${ }^{36}$

As The Financial Times would later note Lonrho was "never an easy company for the outsider to fathom' yet it was clear for all to see that its profits before tax had risen from $£ 158,000$ in 1961 to $£ 16.275$ millon in $1970 .{ }^{37}$ The change in the company's fortunes was driven by Rowland's willingness to 'take a chance in newly independent African countries where established business had become nervous about the future'. ${ }^{38}$ Rowland's decision to expand Lonrho's interests outside of Rhodesia was timely, given UDI. This severely affected Lonrho's ability to operate in the colony, not least when oil sanctions led to the closure of its newly opened pipeline between Umtali and Beira on the Mozambique coast. ${ }^{39}$ On the second day of the rebellion, Rowland flew to Zambia where he registered himself as a Zambian resident to obtain a British passport, and promptly relocated to London. ${ }^{40}$ By 1968 , Rowland was downplaying Lonrho's links with white minority-ruled southern Africa, suggesting that it was only a 'historical accident' that it still possessed assets in Rhodesia. ${ }^{41}$ During 1972 Rowland went as far as to suggest that Lonrho was prepared to sell its assets in Southern Africa, yet this soon changed in 1974 after its South African platinum mines in Rustenburg began to turn a handsome profit. ${ }^{42}$ It is clear to see why Rowland's ideological flexibility in combination with, in the words of The Economist, his 'larger than life' personality that 'resists being tied to conventions and regular expense accounting rather like a roguish hero from a novel about the British Empire', led to Brooks' distrust. ${ }^{43}$

As the existing literature makes clear, Lonrho under Rowland had expanded its interests across the African continent rapidly in the 1960s. ${ }^{44}$ Brooks recognising the company's rapid growth snidely reported that 'Lonrho is bidding fair to become a secondclass Anglo American Corporation'. In the same article Brooks did astutely note that Lonrho's 'insatiable appetite for take-overs and new ventures' had placed a considerable strain on the company's financial resources'. He speculated that Lonrho would not be 'the first conglomerate to run into difficulties through an excess of what one, of kind, could describe as enthusiasm'. ${ }^{45}$ Brooks proved prescient when in the early 1970s Lonrho faced a liquidity crisis and a sharply falling share price. This led to the attempt in 1973 by eight of the more 'establishment' figures on the Lonrho board to remove Rowland from the company. $^{46}$ 
Rowland had previously managed to utilise the backing he enjoyed from Lonrho's small shareholders to destroy the coup at a special shareholders' meeting, held at Central Hall in Westminster on 5 May. In response to reports on the meeting coming out of London, Property \& Finance contended that although 'Mr. Rowland's ability, as a latter day Caesar, to provide bread for his avid shareholders is still a subject of argument, there was no doubt about the quality of the special general meeting and stormy agm'. ${ }^{4}$ It continued by suggesting that 'never has a business event caught the public imagination more; for the occasion was the culmination of a story of intrigue, mystery, assassinations, Big Money, greed, ambition, and all the other ingredients of a modern power game reminiscent of mediaeval times' ${ }^{48}$

Lonrho's chairman, Duncan Sandys, did not fare well in Property \& Finance's coverage. The former Colonial Secretary was described as 'gazing absently around the hall like some dried-up Latin master who had long lost control of the class'. Sandys' day appeared to go from bad to worse, the article contended that 'wearing a bemused expression the aging Mr. Sandys managed to lose his place in the agenda; confused the names of his many fellow directors, ruled himself out of order, and was unable to decide who had the floor'. The following paragraph merely stated, 'not surprisingly, his future as chairman is in doubt'. ${ }^{4}$ When Rowland rose to speak, he received, in the words of the Daily Telegraph, 'an ovation of the sort that is normally accorded to opera singers or Cup-Final winners'. Property \& Finance accused Rowland of 'blandly ignoring the charges of mismanagement, secrecy, and financial juggling' before noting that Rowland's approach to the whole affair came 'more in sorrow than in anger'. The journal grudgingly conceded that Rowland produced 'a masterly performance of low-key technique, all was reasonableness; not a sign was there of the ruthless semi-violent streak of which his directors had complained'. ${ }^{5}$ To one later commentator, the decision by Lonrho's small shareholders to back Rowland against the wishes of the City establishment and much of the financial press suggested that in the age of corporatism, Rowland was a latter day Barney Barnato ... a capitalist hero'.51

In addition to Rowland's willingness to deceive Lonrho's Rhodesian shareholders Brooks also took issue with Lonrho's disposition to engage with newly independent African nations. A clear example can be seen with Rowland's attitude towards the OAU. The Yom Kippur War in the Middle East during October 1973 saw the both the price of oil and antiwestern sentiment in the Afro-Asian world escalate dramatically. Fresh from his victory in the attempted boardroom coup, Rowland approached the OAU with a proposal. Rowland suggested that the organisation's members should source their own oil directly from the 
Middle East, using Lonrho as the broker and shipper. This would enable the African states to shed their dependence on western oil corporations. Rowland had previously intimated his desire to become involved with the OAU, as Property \& Finance was to remind its readers, reporting that Rowland had proclaimed in the early 1970s that 'Southern Africa will be black Africa in 10 to 15 years'. ${ }^{52}$ The OAU appointed a sub-committee to consider the effects of the oil embargo during an Extraordinary Session held in Addis Ababa in November 1973. ${ }^{53}$ Dr Mansour Khaled, Sudan's Foreign Minister, was elected chairman with a remit to ensure the continued flow of oil to OAU countries, in addition to fostering greater financial and technical cooperation between African and Arab states.

During its first meeting the committee authorised the OAU Secretary-General, Nzo Ekangaki, to engage consultants to assist in the technical aspects of securing the transport, storage and distribution of petroleum. Ekangaki approached Lonrho. At the committee's second meeting on 20 January 1974 he stressed that Lonrho enjoyed 'close connections with the Arab oil producing countries', so much so that the Egyptian President Anwar el Sadat had agreed that Lonrho could employee his former Minister of Petroleum to oversee the contract. According the weekly news magazine West Africa, the terms of the contract 'were met with some demur', however given that Ekangaki had signed a contract with Rowland on 11 January the committee was 'thus presented with a fait accompli'. Yet concern arose over Lonrho's interests in South Africa and Rhodesia. ${ }^{54}$ As news of Lonrho's appointment spread, however, there was a chorus of complaints from many OAU members. This led Ekangaki to threaten to resign if his decision to appoint Lonrho was not supported. It was clear, however, that Lonrho's position was untenable and eventually the contract was cancelled at Lonrho's request. $^{55}$

Lonrho's flirtation with the OAU was enough for Brooks to insert an editorial comment into the front page story of the July 1973 issue to "prompt the question whether [Rowland] or Lonrho's continued operations in this country are in the national interest? ${ }^{56}$ Perhaps unsurprisingly, the article which spanned three pages came to the conclusion that 'Lonrho's operations, here or elsewhere, are not in fact in the real interests of this country'. ${ }^{57}$ It therefore suggested that 'few Rhodesian tears should be shed over any misfortunes that he or the group may well still encounter, especially in the sphere of international politics' ${ }^{58}$ Three years later Property \& Finance was still questioning 'Lonrho's continued invulnerability in Rhodesia despite strong criticism (from many quarters) of its support for the OAU and Black Rule'. The column continued by highlighting speculation that Ian Smith had, 'reached a secret understanding with the British Government' to not interfere with 
British investment in Rhodesia, as 'part of the price of British willingness to participate in settlement talks'. This criticism was not solely reserved for Lonrho. The article then suggested that any such agreement may explain why "Anglo American Corporation and similar multinationals have been able to defy the expressed wishes of the Rhodesian electorate with impunity'. ${ }^{59}$ The intention behind this accusation was not only to be damaging to Lonrho and multinational business in general. It was also intended to damage Ian Smith and it should be noted that Smith had recently issued Property \& Finance and Brooks personally, a summons claiming $\$ 25,000$ in damages after the publication in the February 1976 issue of an article entitled 'Smith's Bungling Mafia' ${ }^{60}$

Brooks had Property \& Finance continue its investigation into the influence in Rhodesian politics in what it termed 'Big Money' in its August 1976 issue. In a two-pronged attack on multinational business and Ian Smith, the front-page article suggested that recent controls imposed on Rhodesians wishing to take money out of the country would have been entirely 'unnecessary if the Prime Minister [Smith] and his colleagues had taken resolute action years ago against, for example, the Pro-OAU and scandal ridden Lonrho'. As a result of this inaction, the journal contended that the Rhodesian Front was 'no longer a Party of the small man, in business and otherwise: it allowed its leaders to manoeuvre it into the financial big league of near faceless men' and as a result Rhodesia had become a 'shabby, fifth rate and left leaning autocracy'. ${ }^{61}$

\section{Attacks on Large-Scale Businesses in Property \& Finance}

Brooks' general fear of large-scale business enterprise without firm Rhodesian roots was not confined to Lonrho, as can be seen through his coverage of RST and Anglo. Initially, as detailed above, both Brooks and RST had been very supportive of Federation, but by the end of the 1950s the company was publically voicing misgivings about the political trajectory of Federation. ${ }^{62}$ RST's chairman Sir Ronald Prain publically stated that his main objection was that there was a desperate need to provide for an African political majority, 'in practice and in theory'. In December 1959, Brooks, in agreement with Prain, stated that 'the longer a solution of basic [racial] problems is delayed, the higher will be the price exacted by events'. This prophetic statement outlined Brooks' early belief in the need for African economic and political advancement. At the same time, however, he also outlined his ideas of what of 'liberalism' and 'partnership' were:

But let there be no illusion either, among Africans about the meaning of "partnership". The concept is harsh: it means every man, having been given the 
opportunity, can have no legitimate come-back and must stand on his own feet. It does not mean the politically-easy granting to the African of the means to spend money, which he cannot afford, on expensive European liquor or on large numbers of sweepstake tickets; but it does mean the opportunity, without paternal coddling, to earn the higher incomes which can buy not only these and other commodities but also a wider realisation that the material prosperity does not come without a payment of a price in effort and in some sacrifice of the personal liberty of the kraal. ${ }^{63}$

These comments, and Brooks' early foray into Federal and local politics, reflected Brooks' 'liberal' standing at the time. The United Rhodesia Party (URP) was, from 1953, led by Sir Garfield Todd. Despite his liberal reputation, Todd introduced a range of repressive and restrictive legislation that adversely affected many Africans. ${ }^{64}$ Nevertheless, he is widely regarded as a liberalising force, who was keen to offer improvements for Africans, specifically in terms of health and education. ${ }^{65}$ Todd promoted the ideas of multiracialism and African social, political and economic advancement, but at an extremely slow pace and Africans were clearly regarded as junior partners. ${ }^{66}$ By 1958, the URP had become the United Federal Party (UFP) and was in command of the Federation. Todd pursued his liberal agenda with too much vigour and was accused by many in his own party of being 'out of step with public opinion' ${ }^{67} \mathrm{He}$ was forced to resign as Prime Minister and left the UFP. ${ }^{68}$ Brooks was genuinely involved in liberal politics of the time and was rumoured to have written speeches for Todd and was even spoken of as his 'private secretary'. ${ }^{69}$ Brooks resigned from the UFP following Todd's example and became a member of the Capricorn Society and the Central Africa Party. ${ }^{70}$

Yet by 1962, Brooks' political views had shifted dramatically. Concerned with events in other parts of Africa where colonial powers had withdrawn, Brooks began to fear for the future of whites on the continent. By 1962 it was clear that Federation was to dissolve and that Nyasaland and Northern Rhodesia were to be given independence. Brooks' belief in the capabilities of Africans eroded, and he moved politically to the right. To this end, he no longer supported black advancement in any form and sought to limit the concessions white Rhodesians would make in the event of the end of the Federation. Brooks joined the RF and supported calls for independence for Southern Rhodesia with white settler rule. ${ }^{71}$ This coincided with the change in his views on the role of big business and he made it clear to the readers of Property \& Finance that the privileging of race in the Rhodesias was not businesses' primary concern.

Anglo held an ambiguous position in the eyes of Brooks. ${ }^{72}$ In 1968, Property \& Finance reported positively that Anglo American 'are known to have emphasised the facts of 
life [in Rhodesia] to the London politicians' ${ }^{73}$ Anglo's South African heritage perhaps helped to reassure Brooks that they had an understanding of the Rhodesian situation unlike RST or Lonrho. There was, however, a sign of things to come with the accusation that Anglo 'have acquired increasing influence over Mr Smith and his Ministers as well' ${ }^{74}$ The coverage of Anglo remained positive throughout the 1960s, with Property \& Finance recommending Anglo 'as a must for local investors who want a truly international spread. ${ }^{75}$

This support ended abruptly following the Pearce Commission in $1972 .^{76}$ Brooks, appalled by the proposals, attacked Sir Frederick Crawford, a director of Anglo and former British Governor of Uganda who had urged their acceptance. ${ }^{77}$ Two months later he declared all-out war on both Ian Smith and Harry Oppenheimer in an article titled 'Smith Must Go!'. To Brooks it was 'white liberalism, as exemplified by Mr. Oppenheimer, which whets Black political appetite' ${ }^{78}$ Brooks' decision to highlight white liberalism reflected his belief of the dangers posed to Rhodesian society by the adoption of policies that would move towards gradual racial integration. ${ }^{79}$ In the following issue, Brooks expanded on this point suggesting that Anglo "never miss a trick in attempting, as in South Africa, to use their business and financial influence as a basis for undeviating attempts, either through newspapers or otherwise, to influence public opinion on political matters - invariably to the radical Left' ${ }^{80}$ The article explicitly links Anglo with Lonrho by suggesting that both groups 'subtly ... dabble in matters that they should be careful to eschew as nominees of international interests with little sympathy for the White man's struggle for survival in a sub-continent that (mines and all) he has created' ${ }^{81}$

Liberalism featured prominently in a Property \& Finance article in 1973. In the January issue, Brooks argued that 'as the Federal boom in Rhodesia proved, there is nothing like material prosperity to blunt political awareness: during the extraordinary Federal episode, Rhodesians were induced to accept multiracial concepts that they would never have dreamed of before'. Brooks again demonstrated his distrust of multinational business and its influence on the press, claiming that 'the power of international financial groups was unsurpassed, especially as it controlled most of the opinion-forming media and the governing party'. ${ }^{82}$ This was followed in the May issue with a reminder to the readers of Property \& Finance that Sir Roy Welensky was a close friend of Crawford and that Oppenheimer 'a backer of the ultraliberal Progressive Party in South Africa', influences the main Rhodesian newspapers, through his shareholding in the Argus Group. ${ }^{83}$

Brooks' distrust of Anglo, the Oppenheimer family and South African capital in general grew in 1974 in response to the policy of détente that was introduced by the Prime 
Minister of South Africa, B. J. Vorster. Through détente, South Africa attempted to improve its relations with African controlled frontline states to try and stabilise the region and control the spread of dissent and African resistance. Southern Rhodesia was a major test for détente, as the frontline states keen on a peaceful resolution to the conflict there sought assurances from Vorster he would intervene on the side of Rhodesian African nationalists. Vorster, somewhat surprisingly, applied substantial pressure on Smith to force him to the negotiating table, by withdrawing South African military forces and by slowing road and rail traffic through Rhodesia. ${ }^{84}$ Smith saw these moves as 'the great betrayal' ${ }^{85}$ Brooks, unsurprisingly, was rather unimpressed by these manoeuvres and saw Oppenheimer as directly responsible for influencing the actions of both Vorster and President Kenneth Kaunda in Zambia. ${ }^{86}$ Brooks also believed that Smith had made secret deals with the British, the South Africans and other multinational companies. Indeed, Brooks felt that 'two of the main beneficiaries of détente and Settlement would be the Anglo American Corporation and Lonrho'. ${ }^{87}$ To this end, 'Mr. Oppenheimer and his Anglo American Corporation are exerting all their influence to induce the country to accept Black Rule is inevitable'. ${ }^{88}$ These multinationals were pursuing business interests and profits at the expense of political sensibility, and at the expense of ordinary whites in Southern Africa. In an exposé of Smith's secret negotiations with powerful businesses, Brooks concluded that Smith assisting in undermining white economic interests for the benefits of 'copper-barons' who would swoop in and purchase these interests on the cheap after the introduction of African majority rule:

Although all the assets of individual White enterprise have been stripped, or are in the last stages of stripping, the international copper-barons (Anglo American and RST) have not only received generous compensation, but have been allowed to keep more than a foot in the door: they or their nominees remain the power behind the shaky throne, the conductors of the pro-Kaunda choir, and the prime manipulators of proDétente and pro-Settlement politicians. ${ }^{89}$

\section{Brooks' View on the Changing Nature of Capitalism in the Region}

Brooks' fear of large-scale business came to the fore in the April 1974 issue of Property \& Finance. ${ }^{90}$ An article discussed the 'increasing public resentment over present day trends in capitalist business' in Britain and explicitly suggested that the same developments were also apparent in Rhodesia. It was based on reports of the recent Conservative Party conference in Britain where "the phrase "unacceptable face" was heard repeatedly. To one speaker, the

picture often painted of the economy being governed by "asset-strippers, barely out of puberty, displacing workers from their jobs as a daily occurrence, closing factories, living in company mansions at Shareholders' expense and receiving payments via tax havens, to the 
detriment of the Exchequer" was a "cruel falsehood". The very next speaker, however, appeared less convinced, claiming that 'take-overs leading to increased private monopoly; supranational corporations acting without regard to the national interest or to the welfare of their local employees - those are aspects which we ignore at our own peril'. It is clear from the pages of Property \& Finance over the previous decade that Brooks was more in sympathy with the latter view.

The article quoted Angus Maude, the Conservative Member of Parliament for Stratford-upon-Avon, who claimed that when he viewed the banks' profit figures he asked himself 'if these are our friends, who needs enemies?' Maude linked his view to a shift in the nature of capitalism taking place in the early 1970s. He suggested that even 'experienced and respected industrialists' were 'much less frightened, now, of being taken over by the State ... than they were of being taken over and sacked by some slick City whiz-kid.' There was therefore 'disquiet' that 'present day capitalism was creating disproportionate rewards for the few, whether they were the directors of Lonrho, young entrepreneurs financed by the City of London, or the shareholders of big banks or property companies' ${ }^{91}$

Property \& Finance under Brooks' editorship clearly saw Rowland's Lonrho as an unreliable Rhodesian business concern. Brooks had no love for the more establishment capitalism practiced by Anglo and RST, but his criticisms of Lonrho were often couched in accusations of skulduggery or illegality. The image Rowland and the press created was that of the outsider, of someone challenging the accepted ways of doing business. As The Financial Times reflected on 5 February 1973, Rowland was 'a man with a swashbuckling attitude to the usual business methods, legendary contacts with African leaders and a Midas touch for swelling Lonrho's fortunes'. ${ }^{92}$ His victory over the 'straight eight' in the attempted boardroom coup seemed to underline the shift in power away from respectable establishment figures towards a new breed of capitalists, personified by Rowland, Jim Slater and James Goldsmith. ${ }^{93}$ Brooks' distrust echoes a wider concern, as evidenced by Maude's speech, of the changing nature of western capitalism in the early 1970s. In August 1971 when Management Today published its annual City Growth League, the major gains were for comparatively new concerns, including Rowland's Lonrho. The magazine's editor reflected on this change, suggesting that the 'pickings have gone to self-made, sharp-eyed men who have muscled in on institutional territory and have extended that terrain beyond the dreams of the lifetime career employees of the City's marble halls'. ${ }^{94}$ This refiguring of global capitalism saw Brooks openly despair over its influence in Rhodesia. Having opened with the claim that 'White Rhodesia is essentially a middle-class state', he went on to quote an 
American journalist at length who linked both 'super-capitalism' and communism as 'international' claiming that 'there is no room under either system for free labour or for the free enterprise small businessman' ${ }^{95}$

Brooks' decision to publish this piece at length also reflects his unease about the changing nature of capitalism in Rhodesia and its connections to the global capitalist economy. Peter Cain and Tony Hopkins have famously explored the connections between the City of London and the expansion and retraction of British imperialism. ${ }^{96}$ They stress that by the early 1970s Britain had lost its imperial powerbase and saw its economy threatened by the end of the post-war boom and inflation aggravated by the oil shocks in 1973. The Rhodesian economy experienced similar conditions in the 1970s, contracting with both the global recession in 1971 and the oil shocks during 1973. These events brought the sustained economic growth from the late 1960s to an end and as the Rhodesian Minister of Commerce was to observe, 'we have to run faster merely to stay in the same place'. ${ }^{97}$

By 1975 Brooks' paranoia knew no bounds. No longer content with exposing how multinationals were undermining white influence in Southern Africa, Brooks began publishing a wide range of outlandish conspiracy theories involving some of the biggest names in global finance. One of the most prominent of these was the Rockefeller family. Brooks claimed the Rockefellers had set up the framework of the United Nations, an organisation as bad as the OAU in his eyes, 'and the family now promotes aid to all the enemies of Southern Africa and of the West' ${ }^{98}$ He also accused the Rockefellers of long established links with the communist world (China, Russia and the Viet-Cong) and suggested they were intent on ensuring the success of communist backed black nationalist groups in Southern Africa. In addition, David Rockefeller had long been 'in the van on détente not only with Russia, but also with Red China'.99

These exposés of the Rockefeller family illustrated another of Brooks' conspiracy links; a fear of Jewish connections to both communism and global financial manipulation. In one article on the Bilderberg Group, still a popular target of conspiracy theorists today, Brooks identified a host of Jewish protagonists who had jeopardised Southern Rhodesia's independence and outlined their role in a global conspiracy. ${ }^{100}$ The Beits and the Oppenheimers had help the Bilderberg group establish in Southern Africa with the lure of gold and diamonds. Since then Jewish controlled corporations like Anglo and the Englehard Minerals and Chemical Corporation, had been assisted by people from the Rockefellers, the Rothschilds and other powerful Jews. The key, of course, in the 1970s was none other than Henry Kissinger, 'the most dominant of all Rockefeller protégées and a former refugee from 
pre-War Germany'. ${ }^{101}$ Undeniably, many of these claims and supposed links were pure fancy and impossible to substantiate. They fitted into Brooks' fears and beliefs about the rapidly changing economic and political situation of Southern Africa. These anti-Semitic undertones proved popular at the time and connected to a much longer history of anti-Jewish discrimination in the region. Harry Oppenheimer's father Ernest had been depicted as 'Hoggenheimer the Jew' in a pamphlet distributed by striking white miners in South Africa in the 1920s. ${ }^{102}$ More recently, Sir Roy Welensky had been defeated by the RF's Clifford Dupont in the 1964 Arundel by-election in a campaign mired in crude anti-Semitism. ${ }^{103}$

By 1972, Property \& Finance's readership had grown to 41,000 readers, which further increased to 52,000 in 1975 and 71,000 in 1977. His radical and conspiracy laden assessments of the regional and global situation were very popular with his readers. Partly this was due to the unpredictability of the war in Rhodesia and what form of political survival whites would have. But it was also an attempt to identify those responsible for the fall out in Southern Rhodesia and to lay blame at the feet of others. Brooks made the problems in Rhodesia the cause of people like Oppenheimer and Rowland, who were connected to such unsavoury elements as nationalist leaders, the OAU, communists, international capital and the Jews. This message was well received by 'ordinary' Rhodesians as it exempted them from blame and put the responsibility elsewhere. While the readership of Property \& Finance expanded, the magazine lost advertisers. Smith and the RF put pressure on businesses who advertised in Property \& Finance to withdraw their business. As a result of falling revenues, the magazine shrunk dramatically in size (from an average of 70 pages per issue in the late 1960 s, to 44 pages in 1971 , to 20 pages in 1975 . Colour printing disappeared and the quality of the newsprint fell dramatically. The message and discourse in Property \& Finance not only connected with local audiences, but also similar ones in South Africa, where middle and lower class whites were also concerned for their political and economic futures. Then, in the 1970s, Brooks began calling Smith a 'sell-out'. Smith successfully sued Brooks in a civil case for defamation, after which Brooks left for South Africa. Of the case, Godwin and Hancock noted:

Whether or not Smith wanted him silenced, Brooks believed that the libel suit and the cancellation of advertisements in Property and Finance were all part of a communist conspiracy to destroy the right. The court case began on 6 June 1976, the day after Brooks heard that his son had been accidentally killed while on active service with a PATU [Police Anti-Terrorist Unit] stick. The defendant refused the offer of an adjournment and, according to his own version, addressed Mr Justice Pittman as follows: I have been stripped of my paper, my company, my son; and now I face personal ruin. I have nothing more to lose - or to be taken; but for my son's sake 
alone, and for the sake of many sons, I appear today. He is probably fortunate to be out of the political cesspool that is our - once - beautiful Rhodesia. ${ }^{104}$

After the court case, Property \& Finance closed down. Brooks tried to establish a new publication, titled The Rhodesian Patriot, a very small, modestly produced newsletter proclaiming to be 'a monthly Newsletter replacing Property \& Finance as the White Voice of Rhodesia' ${ }^{105}$ The Rhodesian Patriot was incendiary and failed to find advertisers and financial support. It only lasted eight months and ceased publishing in March 1978. Brooks left Rhodesia for Cape Town, South Africa, shortly after, where he committed suicide in $1984 .{ }^{106}$

\section{Conclusion}

In the August 1975 issue of Property \& Finance Wilfred Brooks reminded his readers that 'Tiny' Rowland had 'made no secret' of his support for the OAU and of his 'even more fervent hope that Rhodesia becomes Zimbabwe'. Brooks suggested to his readers that such an eventuality may reveal a 'hidden quid pro quo' asking 'has not “Tiny" prospered, in the past decade or more, from judicious fishing in murky black political waters? ${ }^{107}$ This article has traced the development of a popular and widespread mistrust of large-scale capitalism, and its potential for disloyalty to the post-1965 Rhodesian state, by the white middle class and smallscale capitalists in Rhodesia through the pages of Property \& Finance. A close reading of the periodical from the early 1960s suggests that a general fear of large-scale business enterprise without firm Rhodesian roots increasingly developed. This was exemplified through the relationship between Wilfred Brooks and the Lonrho chief, 'Tiny' Rowland. Brooks' attitude towards Rowland and Lonrho was shaped by two main features: his distrust of large-scale business and Rowland's desire to expand his businesses into independent Africa. Brooks' attitudes towards the political situation in Rhodesia evolved over time, becoming more radical and right wing as the 1960s and 1970s progressed. Yet in the case of both Rowland and Lonrho his views remained remarkably consistent. This reflects that fact that one would be hard pushed to see Rowland's business decisions as being nothing more self-interested. Rowland, who had never been truly accepted by Rhodesian society, was ahead of the curve in recognising during the dying days of the Federation of Rhodesia and Nyasaland that the future of the continent lay in majority, rather than minority rule. By the mid-1970s Brooks' paranoia was such that he saw conspiracies everywhere and it was no great leap for him to suggest tacit links between the Rhodesian Front, the British government and Lonrho. This point was clearly evidenced in July 1976 when Property \& Finance reported: 
Lonrho's continued invulnerability in Rhodesia despite strong criticism ... of its support for the OAU and Black Rule, has aroused speculation on whether, years ago, Mr. Smith might have reached a secret understanding with the British Government not in any way to interfere with British investment in his country, as part of the price of British willingness to participate in "Settlement" Talks ... The opinion is held that the existence of any such understanding might also help explain why Anglo American Corporation and other such multinationals (whether connected with it or not) have been able to defy the expressed wishes of the Rhodesian electorate with impunity. ${ }^{108}$

Brooks took an ever more conspiratorial approach to understanding the nature of Rhodesia's move towards majority rule in the 1970 s which had the effect of reducing Property \& Finance's advertising revenue while boosting their readership. And Property \& Finance's readership was phenomenal in the mid-1970s. It was widely distributed and read across Rhodesia, and had audiences in Zambia and South Africa too. Brooks attempt to connect to 'ordinary' Rhodesians, as opposed to capitalists and big business, illustrates of one of the key divisions within the white community during a time of radical change. It suggests that largescale capital and the elites of white society were far better placed to navigate the choppy waters of political change than Brooks' idealised 'man-on-the-street'. The former, Brooks believed, were guilt of committing the cardinal sin of placing profit and self-interest before race, while the latter tried to keep intact white rule and racial solidarity that was undermined by the shady deals of politicians and businessmen over whom they had little control.

\section{Notes}

1. Property \& Finance, January 1962.

2. Property \& Finance, August 1976.

3. Ibid.

4. Ibid.

5. Ibid.

6. Ibid.

7. Ibid.

8. Godwin and Hancock, Rhodesians Never Die.

9. Brownell, Collapse; Law Settler State and White, Unpopular Sovereignty.

10. During the Second World War Brooks served as a captain in the Royal Tank Regiment in North Africa. Bulawayo Chronicle, January 12, 1954.

11. Brooks arrived at a time of massive change in Southern Rhodesia. Since 1923, the colony had a 'responsible government', which elected its own legislative assembly through a vote, which was open to all who met certain property qualifications. Constitutionally, Britain had the power to intervene (specifically where it felt rights of Africans may be adversely affected), but in reality, the metropole offered little interference. After the Second World War moves were put in place to form the Federation of Rhodesia and Nyasaland, and the small white community in Southern Rhodesia began actively campaigning for full independence, along the lines of dominion status such as in Canada and Australia. It was decided that Federation was best platform from which to gain independence or dominion status within the Commonwealth. White, Unpopular Sovereignty, 47-8.

12. Bulawayo Chronicle, September 9, 1954.

13. Sunday Mail, May 5, 1968.

14. Our Rhodesian Heritage, December 11, 2002, http://rhodesianheritage.blogspot.com/2012/12/the-story-ofrhodesia-calls.html.

15. Property \& Finance, March 1958, and Property \& Finance, November 1958. 
16. Private email correspondence with Gordon Graham, October 2014. Graham was the founder of Graham Publishing who published the popular Illustrated Life Rhodesia (1968-1979) in Salisbury and had frequent contact with Brooks before his death.

17. Property \& Finance, December 1967.

18. These figures were printed on the front of the magazine from the mid-1960s until its closure in 1976.

19. Tracey, All for Nothing, 199; Godwin and Hancock, Rhodesians Never Die, 64. For more on the shift in Brooks' political outlook see Pilossof and Rivett, 'Imagining Change, Imaginary Futures', forthcoming.

20. For an examination of the RF's populist stance, see Henderson, 'White Populism', 388.

21. Wood, A Matter of Weeks, 634. Ellert also noted, 'The SASCON was strongly supported by the right-wing journal, Rhodesian Property and Finance'. Ellert, 'Rhodesian Security and Intelligence', 91.

22. Bond, Uneven Zimbabwe, 110-1.

23. Property \& Finance, January 1963.

24. Arrighi, 'International Corporations', 367.

25. Cronjé, Ling and Cronjé, Lonrho.

26. Property \& Finance, July 1960.

27. Property \& Finance, January 1963.

28. Ibid.

29. Property \& Finance, December 1963.

30. The new board of directors included, F.E. Buch, Alan Curtis, C.G. Tracey and H.M. van Oldenborgh.

Property \& Finance, December 1967.

31. Property \& Finance, January 1968.

32. C.G. Tracey, All for Nothing, 199.

33. Property \& Finance, December 1968.

34. Hall, My Life with Tiny, 2.

35. Bower, A Rebel Tycoon, 44.

36. Bower, A Rebel Tycoon, 45-60.

37. The Financial Times, September 7, 1971.

38. Ibid.

39. Cohen, 'Oil Sanctions'.

40. Bower, Rebel Tycoon, 93.

41. West Africa, December 28, 1968, 1551.

42. Cronjé, Ling and Cronjé. Lonrho, 81.

43. The Economist, 10 July 1976, 71.

44. See for example Bower, Rebel Tycoon; Cohen, 'Tanzam', 'Oil Sanctions' and 'Corporate Power'; Cronjé, Ling and Cronjé. Lonrho.

45. Property \& Finance, June 1969.

46. Sir Basil Smallpeice was joined by Gerald Percy; William Wilkinson; General Spears; Stanley Dalgliesh; Nicholas Elliot; Major Colin Mackenzie and Alfred Gerber in trying to remove Rowland.

47. Property \& Finance, July 1973.

48. Ibid.

49. Ibid.

50. Ibid.

51. Knyaston, City of London, 475.

52. Property \& Finance, July 1973.

53. The Committee consisted of representatives from seven OAU states: Cameroon, Ghana, Mali, Zaire,

Botswana Tanzania and Sudan.

54. West Africa, March 4, 1974.

55. FCO 65/1521, OAU Press release, 15 March 1974. File reference to the British National Archives, Kew. 56. Property \& Finance, July 1973.

57. Ibid.

58. Ibid.

59. Property \& Finance, July 1976.

60. Property \& Finance, February 1976

61. Property \& Finance, August 1976.

62. Scholars have differed as to how far the decision rested on the company's chairman, Sir Ronald Prain's liberalism, the influence of RST's American majority shareholders or the appeal of cheap black labour. See for example Butler, Copper Empire and 'Business and British Decolonisation'; Cohen, 'Business and Decolonisation' and Phimister 'Corporate Profit'.

63. Property \& Finance, December 1959. 
64. Such as the blanket enforcement out of the Native Land Husbandry Act and the Public Order Act of 1955. 65. Hancock has noted that Todd's claims to be a 'visionary and liberal date only from 1957'. Before that he had spent 'most of his premiership either ignoring or repressing agitation'. Hancock, White Liberals, 61.

66. Mlambo, 'From the Second World War to UDI', 94.

67. As Loney has noted, 'Todd was removed from the premiership because of his relatively liberal racial politics - or, to be more exact, his liberal statements on racial issues'. Loney, Rhodesia, 101.

68. After his resignation, Todd resuscitated the URP and ran against the UFP in elections later in 1958. The UFP won resoundingly. After this defeat, Todd established the Federation-wide Central Africa Party (CAP), which multiracial and sought to 'overcome the barriers of race and colour'. See 'Inaugural congress of the Central Africa Party', June 6 1959, Salisbury, Address by Hon. R.S. Garfield Todd. The CAP collapsed when Todd, in 1960, issued a statement along with one of the nationalist leaders, Joshua Nkomo, calling for the suspension of the Southern Rhodesia constitution and for Britain to send troops to the Federation to restore order. This, according to Terrence Ranger, who was an executive member of the CAP at the time, 'was too much for most members of the CAP to stomach and the party rapidly broke up'. Ranger, Writing Revolt, p. 72.

69. Gordon Steel, 'Letter', Sunday Mail, May 5, 1968; National Archives of Zimbabwe (NAZ), Harvey Grenville Ward, Oral/246; Godwin and Hancock, Rhodesians Never Die, 64-5

70. NAZ, Leo Solomon Baron, Oral/239, 37.

71. There is no shortage of evidence for this shift. See Godwin and Hancock, Rhodesians Never Die, 64-5; C.G. Tracey, All for Nothing, 199.

72. For studies of Anglo American during this period see Hocking, Oppenheimer, and Pallister, Stewart and Lepper, South Africa Inc.

73. Property \& Finance, October 1968.

74. Ibid.

75. Property \& Finance, June 1969.

76. For details of the Pearce Commission, see Blake, Rhodesia, 385-410; Chikuhwa, Crisis, 24.

77. Property \& Finance, February 1972.

78. Property \& Finance, April 1972.

79. For a good exploration of the evolving nature of white liberalism in Rhodesia during this period see Law, Settler State.

80. Property \& Finance, June 1972.

81. Ibid.

82. Property \& Finance, January 1973

83. Property \& Finance, May 1973.

84. Pfister, Apartheid South Africa, 93-105.

85. Smith, Great Betrayal.

86. Property \& Finance, December 1974.

87. Property \& Finance, May 1975.

88. Property \& Finance, June 1957.

89. Property \& Finance, December 1975.

90. Property \& Finance, April 1974.

91. Ibid.

92. The Financial Times, 5 February 1973.

93. For details see Bower, Rebel Tycoon; Slater, Return to Go, Raw, Slater Walker and Fallon, Billionaire.

94. Knyaston, City of London, 435.

95. Property \& Finance, November 1976.

96. Cain \& Hopkins, British Imperialism.

97. Rhodes University, Cory Library, South Africa. Smith Papers, H.B. Musset Cabinet Memorandum,

November 5, 1971, cited in Nyamunda, 'Financing Rebellion'.

98. Property \& Finance, June 1975.

99. Ibid.

100. For details of the Bilderberg group in this period see Murphy, 'Invitation Only', 246-7.

101. Property \& Finance, September 1975. See also Property \& Finance, August 1974. One of the few places that Brooks is still remembered is on anti-Semitic websites, for his 'bravery' in standing up to Smith, the communists and the international Jewish lobby. See a note on Brooks in the anti-Semitic periodical

Instauration, September 1998. Available at http://www.instaurationonline.com/pdf-files/Instauration-1998-09Sept-pt2.pdf. Accessed 15 April 2016.

102. Hocking, Oppenheimer, 244.

103. Wood, So Far and No Further, 239.

104. Godwin and Hancock, Rhodesians Never Die, 195-6. 
105. The Rhodesian Patriot, August 1, 1977.

106. Personal correspondence with Jonathan Waters, August 6, 2015.

107. Property \& Finance, August 1975,

108. Property \& Finance, July 1976.

\section{Acknowledgements}

The authors wish to thank Ian Phimister, Mike Rook, Jonathan Waters, Kate Law and the anonymous reviewers of this journal for their comments on earlier drafts of this article. This work is based on the research supported in part by the National Research Foundation of South Africa (Grant numbers 103547 and 108986).

\section{Disclosure Statement}

No potential conflict of interest was reported by the authors

\section{Corresponding Author}

Andrew Cohen: a.p.cohen@kent.ac.uk

\section{Bibliography}

Arrighi, Giovanni and John Saul, eds. Essays on the Political Economy of Africa. New York: Monthly Review Press, 1973.

Arrighi, Giovanni. 'International Corporations, Labor Aristocracies and Economic Development in Tropical Africa'. In Essays on the Political Economy of Africa, edited by Giovanni Arrighi and John Saul, 105-151. New York: Monthly Review Press, 1973.

Bhebe, Ngwabi and Terence Ranger, eds. Soldiers in Zimbabwe's Liberation War. London: James Currey, 1995.

Blake, Robert. A History of Rhodesia. London: Eyre Methuen, 1977.

Bond, Patrick. Uneven Zimbabwe: A Study in Finance, Development and Underdevelopment. Trenton, New Jersey: Africa World Press, 1998.

Bower, Tom. Tiny Rowland: A Rebel Tycoon. London: Heinemann, 1993.

Butler, Larry. Copper Empire: Mining and the Colonial State in Northern Rhodesia, c.193064. Basingstoke: Palgrave Macmillan, 2007.

Butler, Larry. 'Business and British Decolonisation: Sir Ronald Prain, the Mining Industry andthe Central African Federation'. The Journal of Imperial and Commonwealth History,35, no.3 (2007): 459-484. doi: 10.1080/03086530701523455. 
Brownell, Josiah. The Collapse of Rhodesia: Population Demographics and the Politics of Race. London: I.B. Tauris, 2010.

Cain, P.J. \& Hopkins, A.G. British Imperialism. Harlow: Longman, 2002.

Chikuhwa, Jacob W. A Crisis of Governance: Zimbabwe. New York: Algora Publishing, 2004.

Clements, Frank. Rhodesia: A Study of the Deterioration of a White Society. New York: Praeger, 1969.

Cohen, Andrew. 'Britain and the Breakdown of the Colonial Environment, the Struggle over the Tanzam Oil Pipeline in Zambia'. Business History Review 88, no. 4 (2014): 737-759. doi: 10.1017/S0007680514000749.

Cohen, Andrew. 'Business and Decolonisation in Africa Reconsidered'. The Journal of Imperial and Commonwealth History 36, no. 4 (2008): 641-658. doi:

10.1080/03086530802561024.

Cohen, Andrew. 'Lonrho and Oil Sanctions Against Rhodesia in the 1960s'. Journal of Southern African Studies 37:4 (2011): 715-730. doi: 10.1080/03057070.2011.611286.

Cohen, Andrew. 'Lonrho and the Limits of Corporate Power in Africa, 1961-1973'. South African Historical Journal 68, no. 1 (2016): 31-49. doi: 10.1080/02582473.2015.1118878.

Cronjé, Suzanne, Margaret Ling, and Gillian Cronjé. Lonrho: Portrait of a Multinational. Harmondsworth: Penguin, 1976.

EIR Investigative Team. Tiny Rowland: The Ugly Face of Neocolonialism in Africa. Washington DC: Executive Intelligence Review, 1993.

Ellert, Heerick. 'Rhodesian Security and Intelligence Community 1960-1980'. In Soldiers in Zimbabwe's Liberation War, edited by Ngwabi Bhebe and Terence Ranger, 87-103. . London: James Currey, 1995.

Fallon, Ivan. Billionaire: Life and Times of Sir James Goldsmith. London: Hutchinson, 1991.

Godwin, Peter, and Ian Hancock. Rhodesians Never Die: The Impact of War and Political Change in White Rhodesia c.1970-1980. Harare: Baobab Books, 1996.

Hall, Richard. My Life with Tiny. London: Faber and Faber, 1987. 
Hancock, Ian. White Liberals, Moderates and Radicals in Rhodesia 1953-1980. New York: St Martins, 1984.

Henderson, Ian. 'White Populism in Southern Rhodesia'. Comparative Studies in Society and History, 14, no. 4 (1972), 387-399. doi: 10.1017/S0010417500006770.

Hocking, Anthony. Oppenheimer \& Son. Johannesburg: McGraw-Hill, 1973.

Kynaston, David. The City of London: Volume IV A Club No More 1945-2000. London: Pimlico, 2002.

Law, Kate. Gendering the Settler State: White Women, Race Liberalism and Empire in Rhodesia, 1950-1980. New York: Routledge, 2016.

Loney, Martin. Rhodesia: White Racism and Imperial Response Harmondsworth: Penguin, 1975.

Mlambo, Alois. 'From the Second World War to UDI, 1940-1965'. In Becoming Zimbabwe: A History From the Pre-colonial Period to 2008, edited by Brian Raftopoulos and Alois Mlambo, 75-115. Harare: Weaver Press, 2009.

Murphy, Philip. 'By Invitation Only: Lord Mountbatten, Prince Philip, and the Attempt to Create a Commonwealth "Bilderberg Group", 1964-66'. Journal of Imperial and Commonwealth History 33, no. 2 (2005): 245-265. doi: 10.1080/03086530500123853.

Nyamunda, Tinashe. 'Financing Rebellion: The Rhodesian State, Financial Policy and Exchange Control, 1962-1979'. PhD diss. University of the Free State, South Africa, 2016.

Pallister, David, Sarah Stewart, and Ian Lepper. South Africa Inc.: The Oppenheimer Empire. London: Simon \& Schuster, 1987.

Pfister, Roger. Apartheid South Africa and African States: From Pariah to Middle Power 1961-1994. London: Tauris Academic Studies, 2005.

Phimister, Ian. 'Corporate Profit and Race in Central African Copper Mining, 1946-1958'. Business History Review 85, no. 4 (2011): 749-774. doi: 10.1017/S0007680511001188.

Raftopoulos, Brian, and Alois Mlambo, eds. Becoming Zimbabwe: A History From the Precolonial Period to 2008. Harare: Weaver Press, 2009

Raw, Charles. Slater Walker: An Investigation of a Financial Phenomenon. London: Andre Deutsch Ltd., 1977. 
Slater, Jim. Return to Go. London: Littlehampton Book Services, 1977.

Smith, Ian. The Great Betrayal: The Memoirs of Ian Douglas Smith. London: Blake, 1997.

Uche, Chibuike. 'Lonrho in Africa: The Unacceptable Face of Capitalism or the Ugly Face of Neo-Colonialism?'. Enterprise \& Society, 16, no. 2 (2015): 354-380. doi:

10.1017/eso.2014.31.

White, Luise. Unpopular Sovereignty: Rhodesian Independence and African Decolonization. Durham, North Carolina: Duke University Press, 2015.

Wood, J.R.T. A Matter of Weeks Rather Than Months: The Impasse Between Harold Wilson and Ian Smith: Sanctions, Aborted Settlements and War 1965-1969. Bloomington: Trafford, 2008. 